UDC 556.314:550.4

Vasyl Grygorovych Suyarko,

Doctor of Science (Geology and Mineralogy), Professor,

V. N. Karazin Kharkiv National University, 4 Svobody Sq., Kharkiv, 61022, Ukraine, e-mail: vgsuyarko@gmail.com, https://orcid.org/0000-0002-3693-4767;

Liliya Volodymyrivna Ishchenko,

$\mathrm{PhD}$ (Geology), Department of Mineralogy, Petrography and Minerals,

V. N. Karazin Kharkiv National University, e-mail: 1vishchenko23@gmail.com, https://orcid.org/0000-0002-0848-368X;

Artem Mykhailovich Yerofieiev,

$\mathrm{PhD}$ Student, Department of Mineralogy, Petrography and Minerals,

V. N. Karazin Kharkiv National University,

e-mail: pro100graf@,gmail.com, https://orcid.org/0000-0002-7228-8934;

Valeriy Vasylovich Sukhov,

$\mathrm{PhD}$ (Geology), Head Laboratory, Department of Geology, V. N. Karazin Kharkiv National University, e-mail: donsanchos77@gmail.com, https://orcid.org/0000-0001-5784-5248;

Yanina Stanislavivna Shmorh,

$\mathrm{PhD}$ (Geology), Oil And Gas Institut - National Research Institute,

25 A Lubicz St., Krakow, 31-503, Poland,

e-mail: shmorh@inig.pl, https://orcid.org/0000-0003-2359-2048

\title{
HEAVY METALS IN OILS AND FORMATION OF BITUMEN-HYDROTHERMAL ASSOCIATIONS IN THE ROCKS OF THE DNIEPER-DONETSK PALEORIFT
}

В. Г. Суярко, Л. В. Іщенко, А. М. Срофєєв, В. В. Сухов, Я. С. Шморг. ВАЖКІ МЕТАЛИ У НАФТАХ ТА ФОРМУВАННЯ БІТУМО-ГІДРОТЕРМАЛЬНИХ АСОЦАЦІЙ У ПОРОДАХ ДНІПРОВСЬКО-ДОНЕЦЬКОГО ПАЛЕОРИФТУ. Розглянуто закономірності накопичення важких металів у нафтах та їх взаємозв'язок з утворенням бітумогідротермальних мінеральних асоиіацій у породах рудних полів в межах Дніпровсько-Донецької западини та Донеиької складчастої структури.

Описано прочес тепломасоперенесення у літосфері, що є основним фактором формування як вуглеводнево-металевих флюїдних систем, так і родовищ вуглеводнів та гідротермалітів. Насамперед иче явище пов'язане із альпійською тектонічною активізацією, що призвела до утворення консидементаційних мезозойсько-альпійських складчастих антиклінальних структур, у межах яких функиіонує потужна геохімічна система «вода-вуглеводні-гідротерми». У межах иієї системи спостерігається висхідне розвантаження мінералоутворюючих флюїдів, які характеризуються широким комплексом мікроелементів включно з важкими металами (V, Mn, $\mathrm{Al}, \mathrm{Hg}, \mathrm{Cr}, \mathrm{Fe}, \mathrm{Zn}, \mathrm{Co}, \mathrm{Ni})$.

Досліджено прочеси, щзо призводять до накопичення важких металів у нафтах та утворення бітумогідротермальних асоџіацій у гірських породах.

3'ясовано деякі закономірності вмісту важких металів у нафтах, що пов'язані з особливостями формування покладів в межах різних геологічних структур.

Визначено геохімічну закономірність збільшення концентрачій важских металів з глибиною залягання нафти. Це пов'язано з високими вмістами сірчаних сполук у вигляді гідротермальних сульфідних мінералів, які активно гідролізуються в умовах високих температур і призводять до вилуговування металів та надходження їх у флюїдні системи, де утворюються стійкі сірчані комплекси. Таким чином на контакті металовмімуючих та вуглеводневих флюїдів, щзо мають спільні шляхи міграчїі, цілком можливим є збагачення нафт важкими металами.

Наведено можливості практичного використання результатів дослідження для прогнозування та пошуку родовищ корисних копалин.

Ключові слова: важкі метали, нафта, бітумо-гідротермальні асоиіації, палеорифт, розломи, висхідне тепломасоперенесення, флюїди.

В. Г. Суярко, Л. В. Ищенко, А. М. Ерофеев, В. В. Сухов, Я. С. Шмор. ТЯЖЕЛЫЕ МЕТАЛЛЫ В НЕФТЯХ И ФОРМИРОВАНИЕ БИТУМО-ГИДРОТЕРМАЛЬНЫХ АССОЦИАЦИЙ В ПОРОДАХ ДНЕПРОВСКО-ДОНЕЦКОГО ПАЛЕОРИФТА. Рассмотрены закономерности накопления тяжельх металлов в нефтях и их взаимосвязь с образованием битумно-гидротермальных минеральных ассочиачий в породах рудных полей в пределах Днепровско-Донецкой впадины и Донеикой складчатой структуры.

Описан процесс тепломассопереноса в литосфере, который является основным фактором формирования как углеводородно-металлических флюидных систем, так и месторождений углеводородов и гидротермалитов. Прежде всего это явление связано с альпийской тектонической активизачией, которая привела к образованию консидементационных мезозойско-альпийских складчатых антиклинальных структур, в рамках которых функиионирует мощная геохимическая система «вода-углеводороды-гидротермы»». В рамках этой системы наблюдаются восходящие разгрузки минералообразуюших флюидов, которые характеризуются широким комплексом микроэлементов, включая тяжелье металлы $(\mathrm{V}, \mathrm{Mn}, \mathrm{Al}, \mathrm{Hg}$, $\mathrm{Cr}, \mathrm{Fe}, \mathrm{Zn}, \mathrm{Co}, \mathrm{Ni}$ )

Исследованы проиессы, приводящие $\kappa$ накоплению тяжельх металлов в нефтях и образованию битумогидротермальных ассочиаций в горных породах.

Выяснено некоторые закономерности содержания тяжелых металлов в нефтях, связанные с особенностями формирования залежей в пределах различных геологических структур.

(C) Suyarko V.G., Ishchenko L.V., Yerofieiev A.M., Sukhov V.V., Shmorh Ya.S.

https://doi.org/10.26565/2410-7360-2020-52-07 
Определена геохимическая закономерность увеличения концентраций тяжельх металлов с глубиной залегания нефти. Это связано с высоким содержанием сернистых соединений в виде гидротермальных сульфидных минералов, которые активно гидролизуются в условиях высоких температур и приводят к выщелачиванию металлов и поступлению их в флюидные системы, где образуются устойчивые серные комплексы. Таким образом, на контакте металлосодержащих и углеводородных флюидов, имеющих общче пути миграции, вполне возможно обогащение нефтей тяжелыми металлами.

Приведены возможности практического использования результатов исследования для прогнозирования и поиска месторождений полезных ископаемых.

Ключевые слова: тяжелые металль, нефть, битумо-гидротермальные ассочиации, палеорифт, разломы, восходящиии тепломассоперенос, флюиды.

Introduction. The problem of hydrocarbons and heavy metals' coexistence in geological space is interesting, given its theoretical and practical significance. This has been highlighted in many works of domestic and foreign scientists from different positions due to the lack of unambiguity in the explanation of this phenomenon.

Heavy metals are not only found in most oils, but also occur with bitumens in bitumenhydrothermal mineral associations of ore deposits. The main issue in solving this problem is the study of genetic, spatial and temporal relationships of heavy metals and hydrocarbons. Based on practical material, the authors have tried to highlight geological and geochemical processes of the hydrothermalhydrocarbon natural systems' formation, using case study of the Dnieper-Donetsk Paleorift (DDP) within the Dnieper-Donetsk Depression (DDD) and Donetsk Folded Structure (DFS), allowing us to offer our vision of this geological phenomenon.

The conclusions of the research will be useful for modeling the processes of hydrocarbon accumulations' formation and ore hydrothermal fields.

The subject of the research is oil and bitumen-hydrothermal mineral associations.

The object of the research is geochemical systems of hydrocarbons and heavy metals.

The main material. The Dnieper-Donetsk (Dono-Dnieper) paleorift (avlakogen) is an ancient Paleozoic rift of the Eastern European platform $[7,26]$, which within Ukraine consists of two geological structures: the Dnieper-Donetsk depression (DDD) and the Donetsk folded structure (DFS). The paleorift filled with terrigenous-carbonate-carbonaceous sedimentary rocks, up to $10-20 \mathrm{~km}$ thick, sometimes larger, is characterized by high oil and gas bearing capacity, and DFS is characterized by industrial hydrothermal mineralization $[4,16]$. This is because the geological structure of the paleorift as well as the processes that occur in its geostructure during geological development.

Rifts as tensile structures, together with compression structures - orogens, play the leading role in the functioning of the processes of ascending heat and mass transfer, associated with the migration of deep fluids in the lithosphere. This, in turn, promotes the transfer of gas-liquid fluids through faults and the formation of various oil and gas and hydrothermal (including ore) mineral deposits in zones of tectonic decomposition of sedimentary strata.

In our opinion, the intensity of heat and mass transfer in riftogens is caused by the influence of heat flux from the mantle diapir under the crystal bed. Its excitation during periods of tectonic activation not only determines the directions and velocities of individual lithosphere plates that limit rifthogens, but also causes a periodic increase in the mantle thermal field, which is the major factor in the formation of both hydrocarbon-metal fluid systems and hydrocarbon deposits $[2,3,23]$.

Riftogens by internal structure are divided into symmetrical and asymmetric. The Dnieper-Donetsk paleorift belongs to the first type and consists of separate tectonic ridge-like segments, which are divided by transform transverse faults [31,34,2]. Within these ridge-like depressions, which are in fact separate Paleozoic lithospheric blocks, younger sedimentary Mesozoic-Alpine folded anticline structures characterized by hydrothermal-hydrocarbon fluid dynamics were formed in the sedimentary stratum. This, in particular, led to the formation of hydrocarbon-hydrothermal systems in the fault zones, which affected not only the presence of heavy metals such as $\mathrm{Hg}, \mathrm{V}, \mathrm{Co}, \mathrm{Ni}, \mathrm{Pb}$ and others in the oils of the region, but also the formation of ore hydrothermal mineralization zones in the form of ore manifestations and deposits of mercury and mercury-polymetallic specialization with accessories in the form of minerals such as $\mathrm{Cu}, \mathrm{Ni}, \mathrm{Co}, \mathrm{Fe}$, etc. [16].

Among the deposits of hydrocarbons of DDD, in the rocks of which there is hydrothermal mineralization (among which there is ore mineralization), there should be noted: Khurinskoe, Yuliivskoe, Machukhskoe, Yablunovskoe, Kotelevskoe, and others [17]. Instead, methane gases and naphthenes (bitumens and asphaltenes) constantly accompany the DFS hydrothermal ore fields such as Mykytivske, Druzhkivsko-Kostiantynivske, Slovyanske [11] in the process of ascending unloading along the faults of deep hydrocarbon-hydrothermal streams from the generalized core to the depths structures. In the near-surface layer of sedimentary rocks this led to the formation of strong geochemical barriers, within which there was, first of all, hydrothermal mineral formation [26,31,37,12], as well as oil and gas accumulation [21]. Most productively, these processes took place in the region in the Laramian phase of alpine tectogenesis, which is associated with the 
formation of mercury and mercury-polymetallic deposits [29] with bitumen-hydrothermal mineral associations in which some hydrocarbons and hydrothermalites may, in our opinion, have a paragenetic relation $[3,7,11,10]$.

Hydrocarbons and metal-containing fluids are transported in the earth's crust with the obligatory participation of $\mathrm{H}_{2} \mathrm{O}$ in gaseous and liquid forms. In the process of migration through the zones of open faults, they all form fluid systems "waterhydrocarbons-hydrothermal vents", which at different stages of tectonic activation of faults carry out "injection intrusion" into the sedimentary layer [17]. Groundwater and brines play a huge role in the emergence of physico-chemical barriers $\left(\mathrm{t}^{\circ}, \mathrm{pH}\right)$ within which the processes of hydrothermal mineral formation take place $[26,38,24]$. Within the lower hydrodynamic floor at the depth of 5-6 km, these solutions exist in the region in the form of strong brines with mineralization up to $320.00 \mathrm{~g} / \mathrm{dm}^{3}$ and are characterized by temperatures $\geq 150-200^{\circ} \mathrm{C}$, high $\mathrm{pH}$ values $(\geq 9), \mathrm{CO}, \mathrm{CO}_{2}, \mathrm{CH}_{4}, \mathrm{He}, \mathrm{H}_{2}$ with mercury vapor saturation, and the presence of wide range of trace elements, including various heavy metals, in its composition [19,26,33].

At present, the ascending unloading of highpressure deep waters and brines under the action of heat and mass transfer processes within hydrothermal ore fields and hydrocarbon deposits causes the formation of complex geothermal, hydrogeochemical and hydrogeothermal anomalies. Spatially they coincide with areas of modern upward tectonic movements (up to 5.0-10.0 mm per year) [38]. The formation of such complex hydrodynamic-gasdynamic-geothermal-geochemical anomalies is the evidence of heat and mass transfer processes that occurred in areas of modern tectonic activation of faults $[20,38]$. The fluid flows discharged here differ in the phase and geochemical diversity of chemical elements and their compounds in the form of gases, vapors, liquids and suspensions. Within the ore fields of the region, these streams contain carbon monoxide and dioxide, methane, mercury vapor, and various ions and complexes of heavy metals in liquid solutions [27,37].

Most oil and gas-oil fields, in the oil of which the presence of heavy metals has been analytically determined, are confined to anticlinal structures that accompany the zones of deep faults [9]. This also applies to bitumen-hydrothermal mineral associations of DFS [37]. Hydrothermalites in quartz, the composition of gaseous-liquid inclusions of which constantly include methane and its homologues, also control the faults in the region [6].

These factors may indicate the formation of end-to-end interformational fluid systems, which are favorable for the migration in the earth's crust of both hydrocarbon compounds and heavy metals, in fluid-dynamically active areas of faults $[20,24,38]$.

Hydrocarbons are of both biogenic and abiogenic origin, and the source of heavy metals can be mantle excalates of the weathering crust of the foundation, ore mineralization of sedimentary rocks, as well as fluids of posthydrothermal activation of alpine (laramian) hydrothermal systems $[26,38]$.

The interaction of hydrocarbons with heavy metals in natural geochemical systems is difficult to understand without realizing the possibility of presence of certain amount of abiogenic (synthesized) hydrocarbon compounds in oils. Their presence in bitumen is evidenced by the results of isotopic studies of carbon [24]. In such circumstances, the problem is solved much easier, because it involves the presence of abiogenic hydrocarbons in oils together with heavy metals of mantle-metamorphogenic genesis. The process of generating the synthesized hydrocarbons takes place at a temperature of $\approx 1000^{\circ} \mathrm{C}$ according to the scheme (Fischer-Tropsch synthesis):

$$
\mathrm{nCO}_{2}+(2 \mathrm{n}+1) \mathrm{H}_{2 \rightarrow} \mathrm{C}_{\mathrm{n}} \mathrm{H}_{2 \mathrm{n}+2}+\mathrm{nH}_{2} \mathrm{O} \text {. }
$$

The same reaction in the presence of catalysts in the form of heavy metals $(\mathrm{Co}, \mathrm{Ni}, \mathrm{Fe}, \mathrm{V}$, etc.) can occur at much lower temperatures such as 400$200^{\circ} \mathrm{C}$, which on average corresponds to both lithospheric depths up to $1000 \mathrm{~m}$ and mediumtemperature hydrothermal vents. That is, the natural synthesis of hydrocarbons and, in particular, naphthenes is quite possible not only in the mantle, but also in the lithosphere. Although the question of presence of biomarkers in abiogenic oil, it would seem, is debatable $[13,14]$. In our opinion, the genesis of oil, which has signs of organic and inorganic genesis together, is caused by the multiphase of naphthidogenesis [13]. This gives grounds to claim that all hydrocarbons from gases and oils to bitumen and asphaltenes are polygenic. This approach to the genesis, in particular of heavy hydrocarbons, makes it possible to satisfactorily explain both the presence of heavy metals in petroleum and the existence of bitumen-hydrothermal mineral associations.

Heavy metals in DDD oils have been found [9] within various deposits.

Determination of $\mathrm{V}, \mathrm{Cr}$ was performed on an energy-dispersion spectrometer "SPRUT" SEF 01. Spectrum accumulation time was 600 seconds.

Determination of chemical elements $\mathrm{Mn}, \mathrm{Fe}$, $\mathrm{Co}, \mathrm{Ni}, \mathrm{Zn}, \mathrm{Hg}$ was performed on a wave-dispersion spectrometer "SPRUT" SEF 01M1 (№703-96 in the State Register) by calibration method (the analyst Ph.D. O. O. Baturyn). The measurement time at the peak was $60 \times 4=240 \mathrm{~s}$, and against the background $-60 \times 8=480 \mathrm{~s}$. The value of the pulsestatistical coefficient of variation did not exceed 
Concentration of heavy metals in the oils of various DDD deposits

\begin{tabular}{|c|c|c|c|c|c|c|c|c|c|c|c|}
\hline \multirow{2}{*}{ № } & \multirow{2}{*}{$\begin{array}{c}\text { Depths of } \\
\text { the deposit, }\end{array}$} & \multicolumn{9}{|c|}{ Concentrations of heavy metals, ppm } \\
\cline { 7 - 14 } & & $\mathrm{m}$ & $\mathrm{Mn}$ & $\mathrm{Al}$ & $\mathrm{Hg}$ & $\mathrm{Cr}$ & $\mathrm{Fe}$ & $\mathrm{Zn}$ & $\mathrm{Co}$ & $\mathrm{Ni}$ \\
\hline 1 & Bakhmachske & $3600-3610$ & 0,6 & - & 1,53 & 0,02 & 0,14 & 4,46 & 1,16 & 0,06 & 32,7 \\
\hline 2 & Krasnozayarske & $4200-4500$ & 0,09 & - & - & 0,16 & 0,45 & 221,0 & 3,29 & 0,03 & 2,17 \\
\hline 3 & Kremenivske & $2287-2303$ & 0,82 & 0,21 & 1,37 & - & 0,01 & 1,48 & 0,23 & 0,005 & 1,20 \\
\hline 4 & Khukhryanske & $3266-3291$ & 3,18 & - & 2,43 & 0,20 & 3,90 & 1,42 & 1,51 & 0,002 & 38,1 \\
\hline 5 & Lipovodolinske & $4648-4650$ & 0,07 & 0,21 & - & 0,01 & 0,14 & 4,13 & 0,41 & 0,004 & - \\
\hline 6 & Malosorochynske & $2303-2319$ & 2,17 & - & 2,74 & 0,01 & 0,04 & 0,12 & 0,25 & - & 2,72 \\
\hline 7 & Prokopenkivske & $2516-2523$ & 13,2 & - & - & 0,05 & 0,14 & 9,19 & 1,04 & 0,02 & 31,4 \\
\hline 8 & Raspashnivske & $4037-4259$ & 1,75 & 0,25 & 3,52 & - & 0,61 & 48,5 & 5,60 & 0,03 & 17,6 \\
\hline 9 & Quiver & $1048-1050$ & 2,3 & 0,09 & 4,50 & 0,30 & 0,71 & 1,35 & 0,52 & 0,13 & 0,23 \\
\hline 10 & Solontsivske & $1193-1198$ & 0,16 & 0,21 & - & 0,03 & 0,13 & 28,7 & 2,34 & 0,003 & 1,50 \\
\hline 11 & Talalaivske & $3507-3522$ & 12,2 & - & - & 0,0007 & 0,39 & 31,0 & 1,40 & 0,02 & 2,90 \\
\hline 12 & Perekopivske & $4440-4450$ & 0,13 & - & - & 0,03 & 0,25 & 6,22 & 0,81 & - & 0,50 \\
\hline 13 & Yuryivske & $1617-1625$ & 9,50 & 1,60 & 27,1 & - & 0,04 & 0,69 & 0,35 & 0,006 & 4,22 \\
\hline
\end{tabular}

According to our data, the concentrations of heavy metals in oils correlate with their structural composition and, in particular, with hightemperature fractions of oils [9]. It has been experimentally established that the content of heavy metals is directly proportional to the density and depth of oil, which, in our opinion, can be explained by the physicochemical features of the processes of metal accumulation in porphyrin complexes of heavy-boiling oil fractions. According to our calculations, one of the natural sources of some heavy metals in hydrocarbon fluid systems could be not only mineral-forming hydrothermal vents, but also hydrothermal sulfide minerals. It is binary sulfide compounds that are actively hydrolyzed under conditions of high (over $700^{\circ} \mathrm{C}$ ) temperatures, which lead to leaching of metals with their subsequent entry into fluid systems according to the scheme:

\section{$2 \mathrm{MeS}+2 \mathrm{HOH} \leftrightarrow(\mathrm{MeOH})_{2} \mathrm{~S}+\mathrm{H}_{2} \mathrm{~S} \uparrow$}

As a result, the enrichment of oils with heavy metals at the contact of metal-containing and hydrocarbon fluids that have common migration routes is quite possible. Their migration in oils most often occurs in the form of organometallic complexes or complexes with sulfur. The latter contain hydrocarbon radicals in the form of two unshared pairs of sulfur atoms. This allows them to form complex compounds of the donor-acceptor type with salts of heavy metals having vacant orbits $(\mathrm{Ag}, \mathrm{Pb}, \mathrm{Hg}, \mathrm{Cu}$, $\mathrm{Ti}, \mathrm{Ni}$, etc.) [9].

Another source of heavy metals in naphthoids may be the so-called "dark-colored pelitomorphic polymineral substance" [17] from the Precambrian, Devonian and Coal seams of DDD and other regions of the world. It contains anomalous (100-1000 times higher than Clark) concentrations of rare earths $(\mathrm{Ce}$, La, Nd) and other elements: $\mathrm{Zr}, \mathrm{Ga}, \mathrm{Th}, \mathrm{Ti}, \mathrm{Cr}, \mathrm{V}, \mathrm{Sr}$, $\mathrm{Ba}, \mathrm{B}, \mathrm{U}, \mathrm{Hg}, \mathrm{Li}, \mathrm{Rb}, \mathrm{Cs}, \mathrm{Zn}, \mathrm{Cu}, \mathrm{Mn}, \mathrm{Au}, \mathrm{Pd}$, etc. [19], which have deep origin and are associated with mantle excalates [21].

The isotopic composition of carbon of this substance $\left(\delta^{13} \mathrm{C}\right)$ from - 19.6 to $-23.7 \%$ is much heavier than "organic" in sedimentary rocks, which clearly indicates the influence of mantle fluids during the formation of pelitomorphic substance [16].

Analysis of the distribution of concentrations of heavy metals in oils depending on the depth of sampling from different deposits in the region allowed to establish a clear interrelation between the increase in their concentrations in metals and depth (fig. 1).

To depict the dependence of the depth of the hydrocarbon fluid on its microelement content, the average data on the depths of the deposits, which were approximated graphically by the first approximation, were used. This allowed us to qualitatively illustrate the interrelation between the depth and concentrations of metals in oils $[8,9]$.

Another factor in the natural interaction of hydrocarbons and heavy metals is the formation of "bitumen-hydrothermal mineral associations" in the rocks of DDP that are paragenesis of hydrothermal minerals and natural bitumen in the rocks of ore fields. Bitumens are represented by solid, viscous, and viscous-liquid varieties, which consist of high molecular weight structured hydrocarbons and het- 


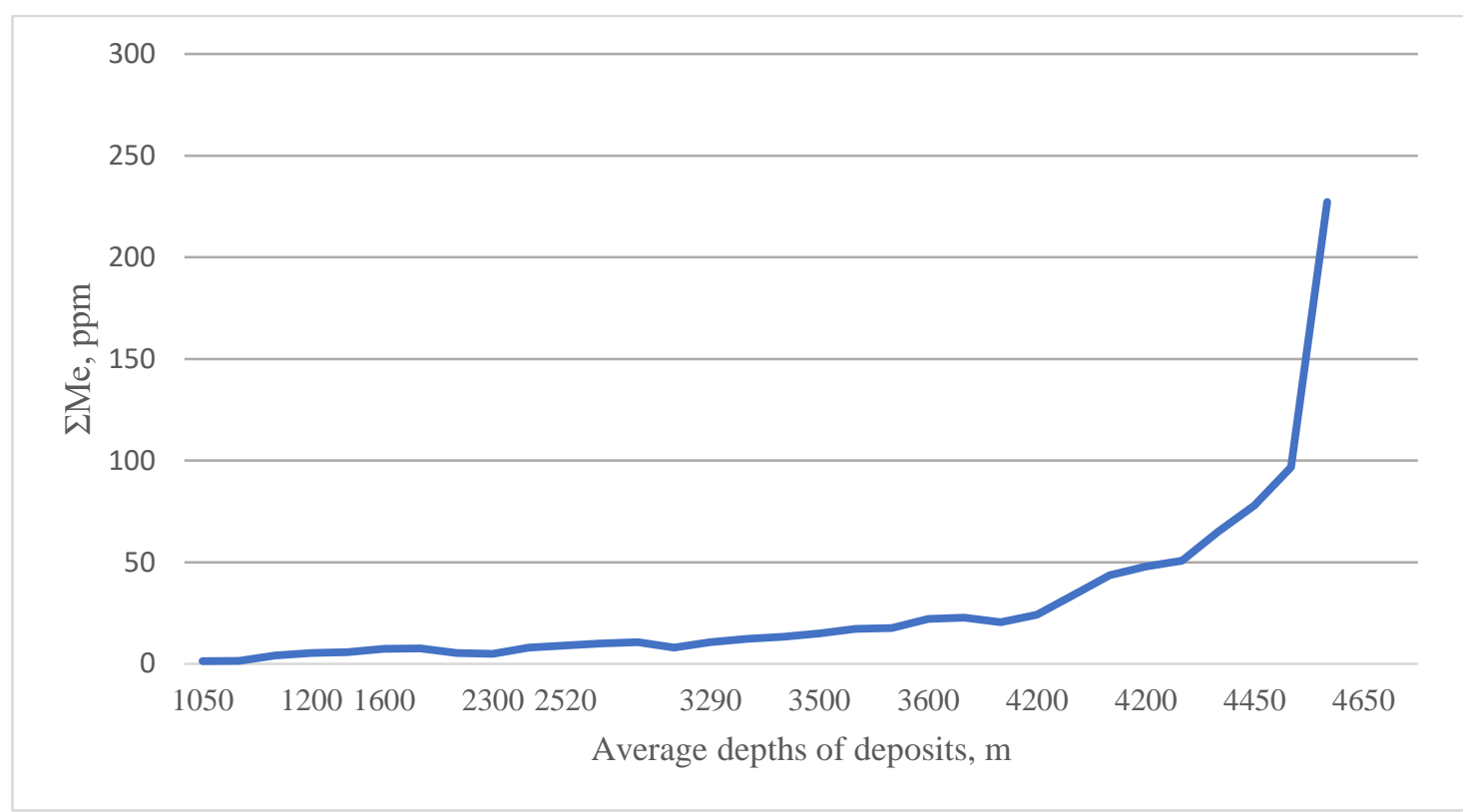

Fig. 1. Dependence of heavy metal concentrations in oils on depth

eroatomic (oxygen, sulfur, nitrogen, metal) compounds. Ore minerals are represented by sulfides of such heavy metals as mercury, lead, zinc $[16,10,11]$.

Bitumen-hydrothermal mineral associations are a global phenomenon observed within hydrothermal ore fields associated with alpine tectonic activation $[22,23,30,35,36,38]$.

The energetic and material basis of bitumenhydrothermal mineral formation is fluid heat and mass transfer [15,38]. This process occurred most intensively during the periods of alpine tectonic ac- tivation (Laramian and Attic phases) [24]. Analysis of the isotopic composition of bitumen carbon from Druzhkivsko-Kostiantynivsky, Mykytivsky and Slovyansky ore fields, performed on mass spectrometers MI 1305 MV (the analysts - V. S. Moroz and L. I. Proskurko) and MI-1201-AG (the analyst A. M. Erofeev), indicates that along with the predominance of organic carbon enriched in ${ }^{12} \mathrm{C}$, they also have an increased amount of heavy isotope $\left({ }^{13} \mathrm{C}\right)$, which may indicate its abiogenic origin (table 2):

Carbon isotope composition in bitumen of hydrothermal ore fields of Donbass

\begin{tabular}{|c|c|c|c|}
\hline $\begin{array}{c}\text { Sample } \\
\text { № }\end{array}$ & $\begin{array}{c}\text { Mineral } \\
\text { substance }\end{array}$ & Sampling point & $\begin{array}{c}\delta^{13} \mathrm{C}, \% \text { o } \\
(\text { PDB standard })\end{array}$ \\
\hline 1 & bitumen & Druzhkivsko-Kostiantynivske ore field & -18.27 \\
\hline 2 & bitumen & Druzhkivsko-Kostiantynivske ore field & -21.73 \\
\hline 3 & bitumen & Druzhkivsko-Kostiantynivske ore field & -18.71 \\
\hline 4 & bitumen & Druzhkivsko-Kostiantynivske ore field & -19.19 \\
\hline 5 & bitumen & Mykytiv ore field & -22.22 \\
\hline 6 & bitumen & Mykytiv ore field & -18.71 \\
\hline 7 & bitumen & Mykytiv ore field & -22.48 \\
\hline 8 & bitumen & Mykytiv ore field & -22.62 \\
\hline 9 & bitumen & Mykytiv ore field & -25.16 \\
\hline 10 & bitumen & Slovyanske ore field & -19.19 \\
\hline 11 & bitumen & Slovyanske ore field & -27.07 \\
\hline
\end{tabular}

Inorganic synthesis of carbon and hydrogen atoms in endogenous fluid streams can take place at temperatures of about $1000^{\circ} \mathrm{C}$ with the formation of compounds of the $\mathrm{C}_{n} \mathrm{H}_{2 n}$ type [24,32], which together with mantle-crustal exglates were transferred to the densification zones in anticlinal structures. Due to the temperature of the process of hydrothermal mineral formation $\left(500^{\circ}-150^{\circ} \mathrm{C}\right)$, light hydrocarbons (gases) left the natural hydrocarbon-hydrothermal system, and the heaviest hydrocarbons, in the form of heavy oils, which were converted into bitumen, took part in mineral formation.

The front of hydrothermal vents in the process of ascending movement through the underlying tectonic channels passed through a large $(\geq 10 \mathrm{~km})$ terrigenous-carbonaceous stratum, capturing not only kerogen scattered in the rocks, but also mobilizing huge masses of organic hydrocarbon compounds 
from coal seams, which eventually led to a significant reduction of the specific content of synthesized hydrocarbon compounds at the final stage of formation of bitumen-hydrothermal mineral associations [24]. This indicates not only that the bitumens of bitumen-hydrothermal mineral associations of hydrothermal ore fields of the region have a polygenic biogenic-abiogenic genesis, but also the formation of such geochemical systems in which they together with heavy metals can enter common fluid flows.

The established features of the interaction of hydrocarbon and metal-containing fluids allow, first of all, to predict oil deposits in the structures of the anticlinal type at great depths. They also make it possible to determine not only the sources of oil generation, but also the ways in which hydrocarbons enter the deposit. In particular, this applies to the explanation of how there is a constant natural replenishment of hydrocarbon accumulations in oil and gas deposits (such as in Shebelinsky deposit).

\section{Conclusions.}

1. Concentrations of heavy metals in oils naturally increase with the depth of their occurrence and their density. Their entry into hydrocarbon streams takes place due to endogenous fluid flows or ore-forming hydrothermal vents, at the stages of alpine tectonic activation of the Dnieper-Donetsk paleorift.
2. The energy-material basis for the formation of fluid hydrocarbon-hydrothermal systems in the rocks of the Dnieper-Donetsk paleorift is the global process of ascending heat and mass transfer in the earth's crust, which occurs along fault zones during alpine tectonic activation (Laramian and Attic phases).

3. Formation of fluid systems in the deep parts of the earth's crust of the region occurs with the participation of synthesized and organic hydrocarbons and mantle exhallates and hydrothermal vents. While these systems are cooling, liquid hydrocarbon frctions (oils) are being enriched with heavy metals, and hydrothermal vents are being enriched with bitumen-forming naphthides.

4. Practical conclusions on the problem of finding heavy metals in oils and the formation of bitumen-hydrothermal mineral associations in hydrothermal ore fields are grounded in reasonable modeling of the processes of formation of hydrocarbon accumulations and hydrothermal ore mineralization. They can significantly increase the efficiency of forecasting and searching for these types of minerals.

The results of the study have not only theoretical but also practical significance and can be used for prediction and search for hydrocarbon accumulations.

\section{References}

1. Багрий И.Д. Гидро- геосинергетическая биогенно-мантийная гипотеза образования углеводородов и её роль при обосновании прямопоисковой технологии / И.Д. Багрий // Геологический журнал. - 2016. - №2. - С. 107132.

2. Бартащук О. В. Системна організація диз'юнктивної тектоніки консолідованого фундаменту Дніпровсько - Донецького палеорифту. Частина 1. Лінеаменти / О. Барташук // Вісник Харківського національного університету імені В. Н. Каразіна, серія "Геологія. Географія. Екологія", 2016. - Вип. 45. - С. $14-22$.

3. Безрук К.О. Геохімія ртуті і підземних водах геологічних структур Донецької складчатої споруди/ К.О. Безрук, Г.В. Лисиченко, В.Г. Суярко. - Київ: Вид-во НАН України, 2013. - 132 с.

4. Белоус И.Р. О региональных структурах, контролирующих сурьмяно-ртутное оруденение Донбасса и Днепровско-Донецкой впадины / И.Р. Белоус // Геол. журнал. - 1986. - Т. 46, № 2. - С. 125-132.

5. Вассоевич Н.Б. Геохимия органического вещеста и происхождение нефти / Н.Б. Вассоевич // Избранные труды. - Москва: Наука, 1986. - С. 324-339.

6. Возняк Д.К. Мікровключення та реконструкція умов ендогенного мінералоутворення / Д.К. Возняк. - Київ: Наукова думка, 2007. - 279 с.

7. Гавриш В.К. Ртутно-вуглеводнева зональність Доно-Дніпровського прогину / В.К. Гавриш, Л.А. Добрянський, М.В. Курило // Доп. АН. УРСР. - 1987. - № 7. - С. 18-21.

8. Єрофєєв А.М. Вміст важких металів у нафтах прикарпатської та Дніпровсько-Донеиької нафтогазоносних провіниій України / A.M. Срофєєв // Science Rise. - 2019. - №9. - C. 27-31.

9. Єрофєєв А.М. Про вмісти, міграцію та концентрацію важких металів у нафтах (на прикладі ДніпровськоДонецької западини та Прикарпатського прогину) // А.М. Срофєєв, І. Березовський // Геологія і геохімія горючих копалин. - 2019. - №1 (178).

10. Іщенко Л. В. Бітумо-гідротермальні асочіачї Дружківсько-Костянтинівської антикліналі (Донбас) / Л. В. Іщеено // Сучасні проблеми геологічних наук: матеріали VI Всеукраӥнської молодіжної наукової конференцїшколи, 14-16 квітня: тези доп. - Київ, 2016. - С. 43-46.

11. Іщенко Л. В. Закономірності розміщення покладів вуглеводнів та зон гідротермальної мінералізащії на територї східної частини Донецької складчастої споруди / Л. В. Іщенко // Вісник Харківського національного університету імені В. Н. Каразіна, серія «Геологія. Географія. Екологія». - 2016. - №45. - С. $38-42$. 
12. Клитченко М.А. Построение геолого-генетических моделей ртутных месторождений на примере Никитовского рудного поля (Донбасс) / М.А. Клитченко, В.Г. Суярко // Геология рудных месторождений. - 1989. - №5. - C. 57-68.

13. Кропоткин П.Н. Дегезаџия Земли и генераџия углеводородов / П.Н. Кропоткин // Журнал Всесоюзного химического общества имени Д.И. Менделеева. - 1986. - Т.31. - №5. - С. 540-547.

14. Кудрявцев Н.А. Генезис нефти и газа / Н.А. Кудрявцев. - Леннинград: Недра, 1973. - 216 с.

15. Кучеров В.Г. Генезис углеводородов и образование залежей нефти и природного газа / В. Г. Кучеров // Научно-технический сборник "Весник газовой науки". - 2013. - №1. - С. 86-91.

16. Лазаренко Е.К. Минералогия Донецкого бассейна / Е.К. Лазаренко, Б.С. Панов, В.И. Павлишин. - Киев: Наукова думка, 1975. - Ч. 2. - 502 c.

17. Лукин А.Е. Литогеодинамические факторы нефтегазонакопления в авлакогенных бассейнах / А.Е. Лукин. К.: Наукова думка, 1997. - 225 с.

18.Лукин А.Е. О происхождении нефти и газа (геосинергетическая конщепция природных углеводородногенерирующих систем) // Геол. журнал. - 1999. - № 1. - С. 30-42.

19. Лукин А.Е. Глубинные факторы формирования Припятско-Днепровско-Длнецкой системы нефтегазоносных бассейнов / А.Е. Лукин, П.Ф. Шпак // Геологический журнал, 1991. - №5. - 27-38.

20. Лукин А.Е. О сквозьформационных флюидопроводящих системах в нефтегазоносных бассейнах / А.Е. Лукин // Геол. журнал. - 2004. - №3. - C. 34-45.

21. Лукин А.Е. Дегазация земли, нафтидогенез и нефтегазоносность. Статья 2 / А.Е. Лукин // Збірник наукових праиь УкрДГРІ. - 2016. - № 4. - С. 79-94.

22. Реддер Э. Флюидные включения как реликты рудообразующих флюидов / Э. Реддер // Геохимия гидротермальных рудных месторождений. - Москва: Мир, 1970. - С. 428-479.

23. Слободской Р.М. Элементорганические соединения и эндогенное рудообразование / Р.М.Слободской // Советская геология. - 1978. - №3. - С. 54-67.

24. Суярко В.Г. Ізотопний склад карбону бітумів гідротермальних полів Донбасу / В. Г. Суярко, Л. В. Іщенко // Доповіді Національної академї̈ наук України. - 2018. - № 11. - С. 63-67.

25. Суярко В.Г. Геохимические особенности подземных вод Донбасса / В.Г. Суярко // Геохимия. - 1988. - № 5. C. $738-747$.

26. Суярко В.Г. Геохимия подземных вод восточной части Днепровско-Донечкого авлакогена / В.Г. Суярко. Харьков: ХНУ им. В.Н. Каразина, 2006. - 296 с.

27. Суярко В.Г. Гидрогеохимические особенности и поисковые критерии ртутных месторождений Донбасса / В.Г. Суярко // Геол. журнал. - 1981. - №2. - 147-149.

28. Суярко В.Г. До питання про можливі причини формування гідрокарбонатно-натрієвих вод у глибинних горизонтах палеозою / В.Г. Суярко, О.М. Істомін // ДАН України. - 2005. - № 2. - С. 114-116.

29. Суярко В.Г. О возрасте ртутного оруденения Никитовского рудного поля / В.Г. Суярко, М.А. Клитченко // Условия локализации сурьмяно-ртутоно и флюоритового оруденения в рудных полях. - Новосибирск: Наука, 1991. - C. 72-74.

30. Уайт Э.Д. Месторождения ртути и ияветных металлов, связанные с термальными минеральными источниками /Э.Д. Уайт // Геохимия рудных месторождений / Э.Д. Уайт. - Москва: Мир, 1970. - C. 479-524.

31. Хаин В.Е. Рифтогенез и нефтегазоносность: основновные проблемы / В.Е. Хаин, Б.А. Соколов // Геологический журнал, 1991. - №5. - С. 3-12.

32. Чекалюк Э.Б. Нефть верхней мантии Земли / Э.Б. Чекалюк. - Киев: Наукова думка, 1967. - 256 с.

33. Чекунов А.В. Геодинамика палеорифтов Украины/ А.В. Чекунов, В.К. Гавриш, Р.И. Кутас // Геологический журнал, 1990. - №6. - C. 3-10.

34. Chorowicz, J. Transfer and transform fault zones in continental rifts: examples in the Afro-Arabian Rift System. Implications of crust breaking // J. Afr. Earth Sci., 1989, 8:(2/4). - P. 203-214.

35. Liu D. Bitumen and Dispersed Organic Matter Related to Mineralization in Stratabound Deposits, South China / D. Liu, J. Fu, R. Jia // Bitumens in Ore Deposits. - 1993. - №9. - C. 171-175.

36. Parnell J. Fluid inclusion constraints on temperatures of petroleum migration from authigenic quartz in bitumen veins / J. Parnell, P. Carey, B. Monson // Chemical Geology. - 1996. - №129. - C. 217-226.

37. Suyako V.G. Bitumen-hydrothermal mineral association in the rocks of the eastern part Dnipro-Donetsk rift / V.G. Suyako, L.V. Ishchenko // Nowoczesna nauka: teoria i praktyka: Mater. II Międz. Konf. Nauk.- Prakt. - 2018. - P. $273-275$

38. Suyarko V.G. Fluid regime and ore water of bitumo-hydrothermal mineral associations in the conditions of Western Donetsk graben / V.G. Suyarko, L.V. Ishchenko, O.V. Gavrilyuk // Visnyk of V. N. Karazin Kharkiv National University, series "Geology. Geography. Ecology”. - 2018. - №48. - P. 113-123. https://doi.org/10.26565/2410-73602018-48-09

Authors Contribution: All authors have contributed equally to this work. 
UDC 556.314:550.4

Vasyl Suyarko,

Doctor of Science (Geology and Mineralogy), Professor,

V. N. Karazin Kharkiv National University, 4 Svobody Sq., Kharkiv, 61022, Ukraine, e-mail: vgsuyarko@gmail.com, https://orcid.org/0000-0002-3693-4767;

\section{Liliya Ishchenko,}

$\mathrm{PhD}$ (Geology), Department of Mineralogy, Petrography and Minerals,

V. N. Karazin Kharkiv National University, e-mail: 1vishchenko23@gmail.com, https://orcid.org/0000-0002-0848-368X;

\section{Artem Yerofieiev,}

PhD Student, Department of Mineralogy, Petrography and Minerals,

V. N. Karazin Kharkiv National University,

e-mail: pro100graf@gmail.com, https://orcid.org/0000-0002-7228-8934;

\section{Valeriy Sukhov,}

$\mathrm{PhD}$ (Geology), Head Laboratory, Department of Geology, V. N. Karazin Kharkiv National University, e-mail: donsanchos77@gmail.com, https://orcid.org/0000-0001-5784-5248;

\section{Yanina Shmorh,}

$\mathrm{PhD}$ (Geology), Institute of Geological Sciences,

25 A Lubicz St., Krakow, 31-503, Poland,

e-mail: shmorh@inig.pl,https://orcid.org/0000-0003-2359-2048

\section{HEAVY METALS IN OILS AND FORMATION OF BITUMEN-HYDROTHERMAL ASSOCIATIONS IN THE ROCKS OF THE DNIEPER-DONETSK PALEORIFT}

Formulation of the problem of the article. The problem of common finding of hydrocarbons and heavy metals in the geological space is very interesting from the point of view of theoretical and practical meaning. It was discussed in many works of domestic and foreign scientists from different positions, stipulated by the absence of ambiguity in the explanation of this fact. It is important that heavy metals are present not only in oils, but also in bitumen of bituminous-hydrothermal mineral associations of ore fields in the region.

The main aim of the article is to research the genetic, spatial and temporal correlation of heavy metals and hydrocarbons.

Research Methods. The processes adducting to the accumulation of heavy metals in oils and the formation of bituminous-hydrothermal associations in rocks have been researched. In particular, the definition of heavy metals in oils from various deposits of the Dnieper-Donetsk basin was performed using the X-ray fluorescence method and the definition of the isotopic composition of carbon of solid bitumen - by mass spectrometric methods.

Results. The processes adducting to the accumulation of heavy metals in oils and the formation of bituminous-hydrothermal associations in rocks have been researched. These processes are associated with ascending heat and mass transfer, which adduct to the unloading of fluid streams, which contained a variety of chemical elements, including compounds of carbon dioxide, methane, mercury vapor, and complexes of heavy metal. Spatially, that process coincides with the anticlannel structures which accompany the zones of deep faults.

It has been found that the concentrations of heavy metals in oils are associated with the peculiarities of deposits formation within different geological structures. Physical-chemical conditions for the formation of hydrocarbon-hydrothermal fluid systems, which involve both biogenic and abiogenic (synthesized) hydrocarbons, were determined. The established geochemical regularity of increasing concentrations of heavy metals with the depth of oil occurrence is associated with high contents of sulfur compounds in the form of hydrothermal sulfide minerals, which are actively hydrolyzed at high temperatures and lead to leaching of metals and their entry into fluid's systems where stable sulfur complexes are formed.

Scientific novelty and practical importance. The formation of hydrocarbon-heavy metal systems within the Dnieper-Donetsk basin occurs with the participation of synthesized and organic hydrocarbons, as well as mantle exhalates and hydrothermal vent. The result is cooling of these systems. Hydrocarbon fractions (oil) are enriched with heavy metals, and hydrothermal vents are enriched with bitumen-forming naphthides. The practical importance of this research is increase in the efficiency of forecasting and prospecting of hydrocarbon deposits at the expense of theoretical modeling of the bituminous-hydrothermal mineral associations formation in ore fields. 
Keywords: heavy metals, oil, bitumen-hydrothermal associations, paleorift, faults, ascending heat and mass transfer, fluids.

\section{References}

1. Bagrij I. D. (2016). Gidro-geosinergeticheskaja biogenno-mantijnaja gipoteza obrazovanija uglevodorodov i ejo rol' pri obosnovanii prjamopoiskovoj tehnologii [Hydro-geosynergetic biogenic-mantle hypothesis of hydrocarbon formation and its role in substantiating direct search technology]. Geological Journal, 2, 107-132.

2. Bartashhuk O.V. (2016). Sy`stemna organizaciya dy`z'yunkty`vnoyi tektoniky` konsolidovanogo fundamentu Dniprovs`ko-Donecz`kogo paleory`ftu. Chasty`na 1. Lineamenty`[System organization of disjunctive tectonics of the consolidated foundation of the Dnieper-Donetsk paleorift. Part 1. Lineaments]. Visnyk of V.N. Karazin Kharkiv National University, series "Geology. Geography. Ecology", 45, 14-22.

3. Bezruk K. O., Ly`sy`chenko G. V., Suyarko V. G. (2013). Geoximiya rtuti i pidzemny`x vodax geologichny`x struktur Donecz koyi skladchatoyi sporudy [Geochemistry of mercury and groundwater of geological structures of Donetsk folded structure]. Ky'yiv: Vy`d-vo NAN Ukrayiny', 132.

4. Belous I. R. (1986). O regional'nyh strukturah, kontrolirujushhih sur'mjano-rtutnoe orudenenie Donbassa i Dneprovsko-Doneckoj vpadiny [About the regional structures controlling antimony-mercury mineralization]. Geological Journal, 46 (2), 125-132.

5. Vassoevich N. B. (1986). Geohimija organicheskogo veshhesta i proishozhdenie nefti [Geochemistry of organic matter and the genesis of oil]. Izbrannye trudy. Moscow, Russia: Nauka, 324-339.

6. Voznyak D. K. (2007). Mikrovklyuchennya ta rekonstrukciya umov endogennogo mineraloutvorennya [Microinclusion and reconstruction of conditions of endogenous mineral formation]. Ukraine, Ky yiv, Naukova dumka, 279.

7. Gavry`sh V. K. Dobryans`ky`j L. A., Kury`lo M. V. (1987). Rtutno-vuglevodneva zonal`nist`Dono-Dniprovs`kogo progy`nu [Mercury-hydrocarbon zonation of the Don-Dnieper depression]. Dop. AN URSR, 7, 18-21.

8. Yerofyeyev A. M. (2019). Vmist vazhky`x metaliv u naftax pry`karpats `koyi ta Dniprovs`ko-Donecz `koyi naftogazonosny`x provincij Ukrayiny`[The content of heavy metals in the oils of the Carpathian and Dnieper-Donetsk oil and gas provinces of Ukraine]. Science Rise, 9, 27-31.

9. Yerofyeyev A. M., Berezovs `ky j I. (2019). Pro vmisty`, migraciyu ta koncentraciyu vazhky`x metaliv u naftax (na pry`kladi Dniprovs ko-Donecz`koyi zapady`ny` ta Pry`karpats`kogo progy`nu) [On contents, migration and concentration of heavy metals in oils (case of the Dnieper-Donetsk basin and the Carpathian Depression)]. Geologiya $i$ geoximiya goryuchy'x kopaly`n, 1 (178).

10. Ishhenko L. V. (2016). Bitumo-gidrotermal`ni asociaciyi Druzhkivs`ko-Kostyanty`nivs`koyi anty`klinali (Donbas). Suchasni problemy`geologichny`x nauk. VI Vseukrayins`koyi molodizhnoyi naukovoyi konferenciyi-shkoly`[Bitumen-hydrothermal associations of Druzhkivsko-Konstantinovskaya anticline (Donbass)]. Ukraine Ky yiv, 43-46.

11. Ishhenko L. V. (2016). Zakonomirnosti rozmishhennya pokladiv vuglevodniv ta zon gidrotermal noyi mineralizaciyi na tery toriyi sxidnoyi chasty`ny`Donecz koyi skladchastoyi sporudy` [Regularities placement of deposits of hydrocarbon and zones of hydrothermal mineralization on the territory of the eastern part of the Donetsk folded structure]. Visnyk of V.N. Karazin Kharkiv National University, series "Geology. Geography. Ecology", 45, 38-42.

12. Klitchenko M. A., Sujarko V. G. (1989). Postroenie geologo-geneticheskih modelej rtutnyh mestorozhdenij na primere Nikitovskogo rudnogo polja (Donbass) [The construction of geological and genetic models of mercury deposits for example of the Nikitovsky ore 's field (Donbass)]. Geologija rudnyh mestorozhdenij, 5, 57-68.

13. Kropotkin P. N. (1986). Degezacija Zemli i generacija uglevodorodov [Degassing of Earth and hydrocarbon generation]. Zhurnal Vsesojuznogo himicheskogo obshhestva imeni D.I. Mendeleeva, 31(5), 540-547.

14. Kudrjavcev N. A. (1973). Genezis nefti i gaza [The genesis of oil and gas]. Lenningrad, Nedra, 216.

15. Kucherov V. G. (2013). Genezis uglevodorodov i obrazovanie zalezhej nefti i prirodnogo gaza [Genesis of hydrocarbons and formation deposits of oil and natural gas]. Nauchno-tehnicheskij sbornik "Vesnik gazovoj nauki", 1, 86-91.

16. Lazarenko E. K. Panov B. S., Pavlishin V. I. (1975). Mineralogija Doneckogo bassejna [Mineralogy of the Donetsk basin]. Kiev: Naukova dumka, 502.

17. Lukin A. E. (1997). Litogeodinamicheskie faktory neftegazonakoplenija v avlakogennyh bassejnah [Lithogeodynamic factors of oil and gas accumulation in aulacogenic basins]. Kiev: Naukova dumka, 225.

18. Lukin A. E. (1999). O proishozhdenii nefti i gaza (geosinergeticheskaja koncepcija prirod-nyh uglevodorodnogenerirujushhih sistem) [On the origin of oil and gas (geosynergetic concept of natural hydrocarbon-generating systems)]. Geological Journal, 1, 30-42.

19. Lukin A. E., Shpak P. F. (1991). Glubinnye faktory formirovanija Pripjatsko-Dneprovsko-Dlneckoj sistemy neftegazonosnyh bassejnov [Deep factors of the formation of the Pripyat-Dnieper-Donets system of oil and gas basins]. Geological Journal, 5, 27-38.

20. Lukin A. E. (2004). O skvoz'formacionnyh fljuidoprovodjashhih sistemah v neftegazonosnyh bassejnah [On CrossFormation Fluid-Conducting Systems in Oil-and-Gas-Bearing Basins]. Geological Journal, 3, 34-45.

21. Lukin A. E. (2016). Degazacija zemli, naftidogenez i neftegazonosnost' [Degassing of the earth, and oil and gas naftidogenesis. Article 2]. Stat'ja 2. Zbirnik naukovih prac' UkrDGRI, 4, 79-94.

22. Redder Je. (1970). Fljuidnye vkljuchenija kak relikty rudoobrazujushhih fljuidov. Geohimija gidrotermal'nyh rudnyh mestorozhdenij [Fluid inclusions as relics of ore-forming fluids]. Moskow: Mir, 428-479. 
23. Slobodskoj R. M. (1978). Jelementorganicheskie soedinenija i jendogennoe rudoobrazovanie [Organoelement compounds and endogenous ore formation]. Sovetskaja geologija, 3, 54-67.

24. Suyarko V. G., Ishhenko L. V. (2018). Izotopny`j sklad karbonu bitumiv gidrotermal`ny`x poliv Donbasu [Izotopic composition of carbon bitumen of hydrothermal fields of Donbass]. Reports of the National Academy of Sciences of Ukraine, 11, 63-67.

25. Sujarko V. G. (1988). Geohimicheskie osobennosti podzemnyh vod Donbassa [Geochemical features of groundwater of the Donbass]. Geohimija. 5, 738-747.

26. Sujarko V. G. (2006). Geohimija podzemnyh vod vostochnoj chasti Dneprovsko-Doneckogo avlakogena [Geochemistry of underground waters of the eastern part of the Dnieper-Donets aulacogene]. Kharkiv, V.N. Karazin KhNU, 296.

27. Sujarko V. G. (1981) Gidrogeohimicheskie osobennosti i poiskovye kriterii rtutnyh mestorozhdenij Donbassa [Hydrogeochemical features and search criteria for mercury deposits of Donbass]. Geological Journal, 2, 147-149.

28. Suyarko V. G., Istomin O. M. (2005). Do py`tannya pro mozhly`vi pry`chy`ny` formuvannya gidrokarbonatnonatriyevy`x vod u gly by`nny`x gory`zontax paleozoyu [To the question of possible causes of the formation of hydrocarbonate-sodium waters in the deep horizons of the Paleozoic]. DAN Ukrayiny', 2, 114-116.

29. Sujarko V. G., Klitchenko M. A. (1991). O vozraste rtutnogo orudenenija Nikitovskogo rudnogo polja. Uslovija lokalizacii sur'mjano-rtutono i fljuoritovogo orudenenija $v$ rudnyh poljah [About the age of mercury mineralization of the Nikitovsky ore field. Conditions of localization of antimony-mercury and fluorite mineralization in ore fields]. Novosibirsk: Nauka, 72-74.

30. Uajt Je. D. (1970). Mestorozhdenija rtuti i cvetnyh metallov, svjazannye s termal'nymi mineral'nymi istochnikami. [Deposits of mercury and non-ferrous metals associated with thermal mineral sources]. Geochemistry of ore deposits. Moskow: Mir, 479-524.

31. Hain V. E., Sokolov B. A. (1991). Riftogenez i neftegazonosnost': osnovnovnye problem [Riftogenesis and oil and gas potential: main problems]. Geological Journal, 5, 3-12.

32. Chekaljuk Je. B. (1967). Neft' verhnej mantii Zemli [Oil of the upper mantle of the Earth]. Kiev: Naukova dumka, 256.

33. Chekunov A. V., Gavrish V. K., Kutas R. I (1990). Geodinamika paleoriftov Ukrainy [Geodynamics of paleorifts of Ukraine]. Geological Journal, 6, 3-10.

34. Chorowicz, J. (1989). Transfer and transform fault zones in continental rifts: examples in the Afro-Arabian Rift System. Implications of crust breaking. J. Afr. Earth Sci., 8:(2/4), 203-214.

35. Liu D. J. Fu, R. Jia (1993). Bitumen and Dispersed Organic Matter Related to Mineralization in Stratabound Deposits, South China. Bitumens in Ore Deposits, 9, 171-175.

36. Parnell J. Carey P., Monson B. (1996). Fluid inclusion constraints on temperatures of petroleum migration from authigenic quartz in bitumen veins. Chemical Geology, 129, 217-226.

37. Suyako V. G., Ishchenko L. V. (2018). Bitumen-hydrothermal mineral association in the rocks of the eastern part Dnipro-Donetsk rift. Nowoczesna nauka: teoria i praktyka: Mater. II Międz. Konf. nauk.- prakt., 273-275.

38. Suyarko V. G. Ishchenko L. V., Gavrilyuk O. V. (2018). Fluid regime and ore water of bitumo-hydrothermal mineral associations in the conditions of Western Donetsk graben, Visnyk of V. N. Karazin Kharkiv National University, series “Geology. Geography. Ecology”, 48, 113-123. https://doi.org/10.26565/2410-7360-2018-48-09 